Kennesaw State University

DigitalCommons@Kennesaw State University

Faculty Publications

$11-2014$

\title{
Social Workers as Social Change Agents: Social Innovation, Social Intrapreneurship, and Social Entrepreneurship
}

Monica Nandan

Kennesaw State University, mnandan@kennesaw.edu

Manuel London

State University of New York at Stony Brook

Tricia Bent-Goodley

Howard University

Follow this and additional works at: https://digitalcommons.kennesaw.edu/facpubs

Part of the Social Work Commons

\section{Recommended Citation}

Nandan, Monica; London, Manuel; and Bent-Goodley, Tricia, "Social Workers as Social Change Agents: Social Innovation, Social Intrapreneurship, and Social Entrepreneurship" (2014). Faculty Publications. 3770.

https://digitalcommons.kennesaw.edu/facpubs/3770 
Running head: SOCIAL WORKERS AS SOCIAL CHANGE AGENTS

Social Workers as Social Change Agents: Social Innovation, Social Intrapreneurship and Social Entrepreneurship 


\begin{abstract}
This article explores and describes social innovation, social intrapreneurship and social entrepreneurship practiced by social workers within human service organizations. Each year, the nature and complexity of clients' problems and challenges experienced by communities continuously evolves and grows. These challenges call for social workers to lead and facilitate social change that can have lasting impact on communities and people. The authors report finding from an exploratory, descriptive study conducted with ten social workers on these practices. The findings point to the need to develop and integrate these contents within social work education, and further promote dual degree graduate programs.
\end{abstract}

Key Words: Social Innovation, Social Intrapreneurship, Social Entrepreneurship, Macro Social Work Practice, Graduate Social Work Education. 


\section{Introduction}

Each year, the nature and complexity of clients' problems and challenges experienced by communities continuously evolves and grows. The economic, social and political climate, nationally and globally, calls for social workers to lead and facilitate social change that can have lasting impact on communities and in people's lives (Lawler \& Bilson, 2010). Further, emphasis is being placed on creating social value and lasting social impact while ensuring financial sustainability of programs and organizations that promote social good (Sakarya, Bodur, Yildirim-Öktem, \& Selekler-Göksen, 2012; Woocher, 2011). This article explores and describes the social innovation, social intrapreneurship and social entrepreneurship practiced by social workers in private and nonprofit human service organizations.

Unfortunately, there is growing emphasis on reducing the governmental role in social welfare, concurrent with shrinking public funding for these causes (Jarman-Rohde, McFall, Kolar, \& Strom, 1997). Moreover, philanthropic donations and charities have experienced a more than $10 \%$ decline in the past 10 years, though financial needs of nonprofits continue rising (Zongker, 2010). These changes are driving management within nonprofit organizations to think "outside the box" to continue effectively addressing endemic social issues (Phills, Deiglmeier \& Miller, 2008; Schmitz \& Scheuerle, 2012).

Though days of relying on philanthropy and grants alone are gone (Germak \& Singh, 2010; Linton, 2013; Nandan \& Scott, 2013), funding challenges can be opportunities for innovation. Social innovation includes any new processes, products and services that address social issues and improve the quality of human life at micro and/or macro levels (Pol \& Ville, 2009). Social entrepreneurship is the establishment of initiatives to implement social innovations. Social entrepreneurs use innovation to create social value and social change through 
a new venture (any organizational forms) in the public, private, citizen or nonprofit sector

(Schmitz \& Scheuerle, 2012). Social intrapreneurship is the application and integration of social innovations within organizations, such as social service agencies. Social intrapreneurs are employees, including social workers, who focus on innovation and creativity that transform the way organizations do business and create social solutions (Pinchot, as cited in Carland \& Carland, 2007).

Ironically, social work has not been actively engaged in discussions and research about these practices. The social work imprint in these practices has been limited; though there is more discussion and writing today on these topics (e.g., blog http:// socialworksynergy.org; Gray, Healy \& Croft, 2003; Germak \& Singh, 2010; Nandan \& Scott, 2013) than probably 10 years ago when Bent-Goodley (2002) authored a pioneering piece on social entrepreneurship and social work. Even though social workers are natural community catalysts for institutional and social change, social innovation, intrapreneurship and entrepreneurship is not automatically affiliated with social work (Zadek \& Thake, 1997).

Human services is at the cusp of participating in, and benefitting from, socially innovative ideas that address social issues, designing and carving new relationships with institutions and organizations across sectors, and integrating private, public and philanthropic support for sustainability of innovative ideas (Phills et al., 2008). These realities are creating avenues for new types of social work practices at programmatic and organizational levels. Today, these professionals have to simultaneously work at multiple levels and tap more than government funds for financial sustainability of ideas (Mulroy \& Shay, 1997). As “an organization is freed from dependence on government contracts and earmarked charitable 
donations, the organization" can be more innovative and creative (Germak \& Singh, 2010, p. 91).

Few studies have explored the influence of opportunities on pursuit of social innovation, social intreprenurial and social entrepreneurial activities (Pantry \& Griffiths, 2000; Salamon, Geller \& Mengel, 2010; Schmitz \& Scheuerle, 2012). Such studies are almost absent in social work. Without adequate research, little can be said about the relationship between opportunities, innovation, and strategies needed to discover and utilize growing opportunities (Companys \& McMullen, 2007). Germak and Singh (2010) and Nandan and Scott (2013) make a sound case to explore and teach these concepts to social work students. Social workers are realizing that "business as usual" is not creating financially sustainable social change. Against the backdrop of current literature in the fields of social innovation, social entrepreneurship and social intrapreneurship, this article presents data on social workers engagement in these practices in a Midwestern State.

\section{Literature Review}

As the concepts of social innovation, social intrapreneurship and social entrepreneurship have captured interest across a wide range of academic disciplines (e.g., business, nonprofit management, sustainability, entrepreneurship, computer science, leadership, engineering), researchers in these fields are coalescing around the notion that intractable social problems become tractable with innovative solutions. The literature review is structured around these three practices or strategies. Social innovation is a large concept and practice that could be implemented through social intrapreneurship or social entrepreneurship.

\section{Social Innovation}


The demand for social services is growing exponentially, wherein, government, businesses and nonprofits will need to work in tandem to find creative solutions to effectively leverage what each sector does. New kinds of organizations are emerging at the intersection of the public, private, and nonprofit social sector, called the "for-benefit sector" (Aspen Institute, 2009). According to the Executive Director of Rockefeller Foundation, Judith Rodin, the opportunity to innovate, with all sectors involved in the process, is real, because the resource growth is not keeping pace with demand growth (Nee, 2009). Fortunately, political leaders are finally embracing the term social innovation (Phills \& Nee, 2009).

Innovations have the potential to improve quality and delivery of social services, though risk taking is inherent in their implementation (Brown, 2010). Innovation in the social sphere means accomplishing more with less, working together, leveraging resources, sharing data and creating models for change that are sustainable. Examples of social innovations may be when a nonprofit barters, with a business, the excessive goods donations it receives for alternative goods that are normally used by their clients. Another example may be when several nonprofits consolidate their purchasing for reduction in cost of goods because of economies of scale-a process usually not followed in the nonprofit sector. Young (2011) defined social innovation as "a novel mechanism that increases the welfare of the individuals who adopt it compared with the status quo" (p. 2185). Social innovation incorporates both idea generation and social sustainable outcome (Phills et al., 2008). Innovative programs are "a new or different way to address a societal problem or pursue a charitable mission that is more effective, efficient, sustainable, or just than prevailing approaches" (Salamon et al., 2010, p. 2). A goal of social innovation is to meet social needs while the innovation is developed and diffused through organizations, new (social entrepreneurship) or existing (social intrapreneurship) (Munshi, 2010). 
Social innovations resulting from community-based collaborations are very effective because they build on the strengths of the community and partners with residents and clients; the latter are closest to the social problem and understand the nuances that often professionals cannot (Mulroy \& Shay, 1997). This notion is a unique social work perspective that the profession brings to the social innovation literature and practice. Involving clients in all stages of development of the new idea and the delivery of the new idea, can strengthen not only the social innovation but create sustainability for the implementation of the idea as well (Nandan, London \& Blum, in press). Involving members of marginalized communities in designing and developing the new ideas can help build those capacities (Sakarya et al., 2012). User driven innovation, such as where end users of products and services are given voice in solution development, is far more sustainable than an idea generated by an entrepreneur alone. This approach upholds social work principles of client self-determination and creating empowering environment for them (Mulroy \& Shay, 1997; Tedmanson \& Guerin, 2011).

The John Hopkins Listening Post (Salamon et al., 2010) conducted a study of over 400 nonprofit organizations pertaining to their ability to launch innovative projects and ideas. $82 \%$ of the respondents had implemented at least one innovative project in the past five years, and of these, $52 \%$ had implemented the project in the past 2 years. Surprisingly, innovation was more prevalent among large nonprofits than originally imagined. Adequate funding was one major impediment to implementing innovative ideas or taking them to scale. Contributions and grants were the primary sources to keep the organizations in business, not necessarily to grow them. Other impediments included: "[1]ack of staff skills and expertise," "lack of staff time and lack of needed technology" (Salamon et al., 2010, p. 7) and a lack of staff time and resources to attend conferences and read periodicals (p. 4). 
Brown (2010) and Cohen (1999) identified challenges to innovation: resistance to change and managers feeling threatened by change ideas, high turnover of staff, challenges in implementation with high staff turnover, lack of incentives and regulatory frameworks that inhibit socially innovative ideas, belief that all change can originate at the top only, and finally the risk and vulnerability of the service users may make it difficult for service providers to try new ideas. Nonetheless, involving employees in designing and implementing socially innovative ideas not only improves practice but also can be motivating and empowering for employees (Cohen, 1999).

Today, we need social innovators who not only create new ideas but also change the larger context for the innovation to prosper (Moore \& Westley, 2011). With macro practice skills, such as administration, policy practice, and community organizing, social workers are equipped to change systems and contexts. Social innovators could ultimately function like social intrapreneurs or social entrepreneurs, dependent on how they implement the innovation

\section{Social Intrapreneurship}

Intrapreneurship is more common in the business literature than social intrapreneurship in the social science literature. Burgelman (1983) coined the term "corporate entrepreneurship" and internal corporate venturing to refer to what Bouchard and Basso (2011) define as social intrapreneurship, an entrepreneurial behavior exhibited by employees within an organization. "A person who focuses on innovation and creativity and who transforms a dream or an idea into a profitable venture, by operating within the organizational environment" (Pinchot, as cited in Carland \& Carland 2007, p. 84). Brunaker and Kurvinen (2006) define intrapreneurs as 
proactive change agents who recognize opportunities, potentials and meanings from seemingly unimportant events.

Management structures (e.g., support, boundaries, autonomy at work, rewards and reinforcements, time availability etc.) and processes can play a key role in promoting social intrapreneurs. Creating intrapreneurial teams, recruiting new employees who are motivated to innovate and "think outside the box," and establishing internal research pods that promote innovation and place such endeavors within strategic plans, are some ways of promoting SI. Sometimes managers cannot operate as intrapreneurs when their role is to reduce risks (Carland \& Carland, 2007). Individual characteristics of desire for autonomy, need for achievement, internal locus of control, and risk-taking create propensity for social intrapreneurship among individuals (Hornsby et al. as cited by Schmitz \& Scheuerle, 2012). Schmitz and Scheuerle (2012), in their study of social intrapreneurial organizations, found that these organizations practice far more advocacy than new startup ventures and also they engage in continuous innovations within the organization than new startup social enterprises.

Carland and Carland, (2007) make several recommendations for nurturing intrapreneurs to thrive within organizations. Some of the poignant elements they identify are that: risk taking must be permitted while balancing the organization's interests, credit must be shared where appropriate, teams for innovation must be created, and research and data collection must be completed to sell the idea to administrators. Innovation, risk-taking (e.g., political, financial) and proactiveness (intention to lead in the industry or market) are overlapping characteristics in social entrepreneurship and social intrapreneurship (Schmitz \& Scheuerle, 2012).

\section{Social Entrepreneurship}


Research shows that when economy is unstable, it presents more opportunities for entrepreneurial activities (Light, 2008). Evidence also suggests that socially entrepreneurial opportunities arise during specific punctuations in history. During these periods, the prevailing wisdom and paradigm is unable to explain and solve the existing challenge and inequalities. Today, we are in such punctuation, as history unfolds (Light, 2009). Light points to the absence of interest among social entrepreneurs and their funders to research the field and develop strategies to support social innovation activities. Notwithstanding the lack of interest in conducting research on social entrepreneurship, this field is attracting a new generation of change agents who are creating sustainable impact and addressing intractable social problems through innovative solutions by changing the existing social equilibrium (Light, 2008). Interestingly, "[m] any governments around the world [are encouraging] community-based social entrepreneurship because of its ability to transform society" (Ratten \& Welpe, 2011, p.283).

Although some societies encourage change and innovation, others prefer to be more conservative and traditional (Hayton, George \& Zahra, 2002). Circumstances and contexts change with changing economic, political, social and demographic conditions. The ability to connect "seemingly unconnected dots" or conditions, and see opportunities in circumstances is an entrepreneurial skill. Juxtaposition and confluence of conditions creates circumstances that entrepreneurs find lucrative for new products/services that can address social issues (Barons, 2006). Barons recognized that the ability of social entrepreneurs to connect dots in nonconventional fashion is influenced by their previous life experience and academic training.

Jane Addams was our profession's social entrepreneur because she introduced innovative community-based approaches to social work that were nationally replicated (Barendsen \& Gardner, 2004). However, there is scant attention to social entrepreneurship in the social work 
literature and pedagogy (Nandan, London \& Blum, in Press; Nandan \& Scott, 2013; Short, Moss \& Lumkin, 2009), despite the fact that social workers are particularly equipped to balance the needs of clients and communities with those of the various stakeholders who may be involved in a socially entrepreneurial venture (Germak \& Singh, 2010).

Several definitions exist for the term "social entrepreneur" and "social entrepreneurship." Simply, social entrepreneurs espouse both social and economic goals (Zahra, Rawhouser, Bhawe, Neubaum, \& Hayton, 2008). Dacin, Dacin, and Matear's (2010), Short et al., (2009) as well as Bacq and Janssen (2011) have conducted a thorough assessment of the literature on this topic and have presented several variations of the definitions. Tapsell and Woods (2010) perceive social entrepreneurship as "the construction of opportunities for transformative social change through innovative activities occurring within or across economic and social communities in a historical and cultural context" (p. 539).

Social entrepreneurs - as individuals, groups or organizations - are innovative, proactive, risk takers (Helm \& Andersson, 2010; Praszkier \& Nowak, 2012) attempting to create sustainable community, social, or industry-wide change for addressing endemic social problems. Their innovation and risk tolerance normally exceeds those of a typical human service organization manager or a community practitioner. Through their ability to galvanize organizational actors and individuals, social entrepreneurs build social capital and social networks that foster project sustenance. They identify, evaluate and exploit opportunities with the aim of creating social value by using a wide range of market-driven and other resources, to create social transformation (Bacq \& Janssen, 2011, p. 388; Vasi, as cited by Ratten \& Welpe, 2011). 
Germak and Singh (2010) regard social entrepreneurship as a hybrid of macro social work practice and business skills and activities. Depending on the scope of change being created by social entrepreneurs, they can operate as social bricoleurs (addressing small scale social issues), social constructionists (opportunists who fill the gaps created by market failure impacting disenfranchised populations) or social engineers (address social problems by changing larger social systems). In each of these instances, social entrepreneurs are tuned into recognizing opportunities in the environment, though the level of risks they take can vary greatly based on the scale of change they are creating (Zahra et al., 2008).

Social entrepreneurship behaviors can create social value (Peredo \& McLean, 2006). By pursuing opportunities to initiate social change and address social needs, social entrepreneurs create social value (Dees, 1998; Mair \& Marti, 2006). Social entrepreneurs meet social needs in a sustainable fashion and thus alleviate social problems, enhance social condition, and promote social change. They innovatively combine social needs, with social assets and create social impact (as cited by Perrini, 2006). According to Brinckerhoff (2000), social entrepreneurs add value to existing services and take reasonable risks on behalf of the people they serve by ensuring both social and financial returns on their investments. Social entrepreneurial activity is produced through innovation, proactivity, and risk taking, the three primary components of entrepreneurial orientation (Mort, Weerawardena \& Carnegie, 2003).

In summary, social workers can be a source of innovative practice identifying and implementing new ways to address social problems. They can be intrapreneurial within organizations, designing more effective and efficient operations and partnerships. Moreover, they can be social entrepreneurs, joining forces with community members, government, and business partners to start ventures that creatively meet social needs. The primary goal of the 
current research was to explore the evolving context of social work practice in different human service organizations, and their strategic responses to the context through social innovation, intrapreneurship and entrepreneurship. Another goal was to assess social workers' preparedness for these strategic responses.

\section{Method}

This exploratory study included in-depth interviews with ten social work, administrators and practitioners, in a Midwstern metropolitan city. Through snowball sampling, key informants were identified from all levels within the organizations and invited to participate. The sample frame was developed from a comprehensive list of local human service organizations maintained by a university-based training organization. The Executive Director of the training organization helped in identifying organizations, and individuals who were perceived to be creative and innovative in the city. Invitations via e-mail were sent to $30 \mathrm{key}$ informants and 20 volunteered to participate in the study. Ten of the respondents had completed graduate education in social work. The other ten held degrees in other disciplines (e.g., business). Here we report only the data from the ten social workers. Their demographic data are presented in Table 1.

A range of agencies and field of practice was represented in the sample-mental health, domestic violence, adult day care, boys group home, comprehensive social service organization, children services and health care foundation to name a few. Some respondents were practicing in the field since the 1970s, while others had entered the profession after 2000 . They were operating as Executive Directors, case managers, private practitioners, or Chief Executive Officers, overseeing staff and volunteers. Many respondents had taken courses in other fields besides social work and they had a range of management and clinical experiences in their background. 
<Insert Table 1 here>

Thirteen open-ended questions were used during the semi-structured interview and the three foci of the questions included assessing the: (1) dynamic and complex social, political and economic climate surrounding the organization, (2) strategies (programs, ventures, interventions) used by participants to be more responsive to the changing context, and (3) their level of academic preparedness to launch social innovations through social intrapreneurship initiatives and social entrepreneurship ventures. Data collection included $2-3$ hour-long face-to-face interviews with participants that were taped and later transcribed, verbatim. Transcripts were mailed to each participant to ensure validity of data; four participants returned transcripts with modifications; transcripts were independently coded.

Content analysis is the process of coding and categorizing the primary concepts in the data. Inductive analysis is when categories, themes and patterns emerge from the data rather than being imposed by the researcher. Usually, respondents use indigenous concepts and sensitizing concepts, often derived from literature and theories, are used by a researcher (Patton, 2001). In this study, during content and inductive analyses, the four transcript coders - three graduate research assistants (GRAs) and one of the three researchers-employed indigenous and sensitizing concepts. The GRAs had read extensive literature on social innovation, social entrepreneurship and social entrepreneurship to assist them with coding. Each coder was provided separate electronic files of data with clear instructions to not discuss the research with each other, in order to prevented biases during coding.

All responses to a question were first grouped together in independent electronic files; hence, there were a total of thirteen files and for each of the thirteen questions, there were ten responses. First, each response was independently coded, with concepts used by respondents or 
concepts from the literature; subsequently, all responses for a particular question were read consecutively to identify themes, i.e., recurring codes or categories in the data. This process was followed by each of the four independent coders. Only themes that were identified by at least two of the four coders are included in this article. At the outset of analysis, the authors determined to include themes that had at least $50 \%$ inter-rater reliability, i.e., two of the four raters agreed on the themes. The themes reported in this article met this criterion. Patterns were noted among some themes from the data (Patton, 2001).

\section{Results}

Themes are organized into three aforementioned categories and patterns are described towards the end of this section.

\section{Context}

Service Providers' Context. Participants noted the high level of volatility in the political and economic climate, and major changes in the social and cultural context of their clients. On the one hand, funding for human services was decreasing from the public sector and philanthropic organizations; on the other hand, number of competitors among nonprofit organizations was increasing. The vicissitudes of both public and private funding sources deterred organizations from conducting long-term planning. The public system for qualifying clients for services was reported as being grossly inefficient. One participant stated:

[I] is very difficult to penetrate the [philanthropic funding stream] if you don't have a clear, concise, accountable presentation for that. That's one thing that I have really learned in the last five years, is how competitive that is and how the dollars can dry up. [With public level of financial support] by the time it trickled down and was disbursed, funding was difficult to understand and limited funding...

Another participant stated:

"I think just like any other nonprofit in town especially with current economic climate, I think things are tight. [They are] more tight than they usually are and most investments 
are down. It will be interesting to see what will happen by the end of this year [with job loss, foreclosures etc.] how hard it was for us to meet our budget needs...90\% of our budget comes from individual giving. That is always a challenge that charities like ours are looking at."

A fair amount of duplication and redundancy created more frustration for service providers and clients - undermining the potential for an effective service delivery system. Public sentiment that people who are financially poor are lazy and not deserving of assistance abounded. One participant stated:

The fast food industry and the CNA industry has it very well figured out where you employ these women thirty hours a week or less and you do not have to give them benefits or sick time, vacation time.... you know you are unable to keep your job there. So the average employment for folks in the working poor [category] is about four and a half months...Poverty is the main factor of, you know, just all the inconveniences that comes with being poor....[Unfortunately, in our state] if you make minimum wage and have three children, you don't qualify for daycare assistance...I feel like our society...is very reactive. We are reacting to the war, supposedly. We are [regularly] reacting to something... [I act as the] voice of a movement, helping others whose voices are unheard to be heard. My title is a ... and I feel like I am always...fighting, trying to get their voices heard, because at the end of the day, they are so freaking tired that it is hard for them to get out there and volunteer for political campaigns or get on TV to talk about social issues or go down to the [capital]."

Increasingly, insurance companies were reducing the number of sessions with therapists on the one hand, and on the other, referrals to long-term inpatient treatments were declining. Several nonprofit organizations were losing their traditional contracts with the federal and/or state government. Participants noted an enhanced need for accountability in their service delivery, as well as constant efforts to hold on to their share of public funding. As one participant stated:

[P] rivatization of [services for children] ...was the biggest issue out there [5 years ago] that we felt we needed to respond to....Also, there was greater demand for accountability, more rules and regulations, funders [expecting] specific outcomes...[mandating us to] evaluate the things we were doing...the environment was creating new competitors for us. And those new competitors were for-profit organizations....That caused us and pointed us to come together [through] the creation of [an umbrella organization 
occurred through a joint venture across 5 organization] to become a much larger system in order to be more competitive in the environment.

Client-mix. The challenges encountered by the working-poor population entrenched most members of this segment to remain in poverty, especially when most social service and institutional responses were reactive, at best. The attitude towards mental illness and provision of mental health services was very poor, and had been so for a very long time in this county. Additionally, in the past five years, new groups of people needed mental health servicesdomestic violence victims, Latino youth, and people with disabilities. Domestic violence clients were coming into shelters with complex needs-emotional, physical and substance abuse related. Emotional and cognitive needs of clients that were needing adult day care services was also changing-younger people diagnosed with Alzheimer's' disease, more persons with dual diagnosis in the population suffering from cognitive disability, and larger number of veterans suffering from serious post-traumatic stress disorders. Loss of job was creating emotional strain in all economic strata, as was internet-based challenges. One participant stated:

[Our clients into the domestic violence shelters are coming with] mental health issues, substance abuse issues and physical health problems [all of which need attention while they are with us] ... They have been living in survival mode all this time, so being healthy has not been their top priority....[Additionally], as we see these declines in our economy, we will see more and more where people are staying in an abusive relationships because they don't have any other options....

Although the changes were frustrating, participants also perceived some of the changes as opportunities for designing innovative strategies to address the social issues.

\section{Social Innovation, Social Intrapreneurship and Socially Entrepreneurship}

Developing partnerships and networking was key to survival in the highly volatile political economy. The participants watched the political rhetoric and zeitgeist before carving out a niche and a strategy for impacting the social issue in a more sustainable fashion. They 
utilized some combination of policy practice—value clarification, analysis, interactional and political (Jansson, 2011)—community organizing, social work practice and administration skills.

One participant stated:

All that you learn in social work is relationship [building], authentic relationships... That serves you well in [social] entrepreneurship... And a few authentically built relationships, authentically listening to people, you learn more about listening than talking, ask a lot of questions, surround yourself with a lot of good people, have a passion and a mission for what you are doing and based on risk assessment, determine if there is a need, a lot can be done...Mr. Kauffman used to say... "money does not solve problem, people solve problem...."

Participants tracked trends by regularly watching grants that became available and legislative bills at state and federal levels that could impact their respective agency. Additionally, cross-sector alliances - through contracts and MOUs - were carved out by participants in order to innovatively and sustainably respond to the changing context. Some participants designed seamless delivery systems and "one-stop-shop" for their clients that were more proactive than reactive, and that attended to systemic challenges, moreso, than to individual changes and adaptations. These participants recognized that holistic approaches to service design and delivery was instrumental for assisting clients with multifaceted chronic issues. They perceived the evolving context as potential opportunity for not only innovating to stay ahead of the curve but for generating revenue as well. As is evident in Table 2, participants were socially intrapreneurial or socially entrepreneurial through their innovative activities.

$<$ Insert Table 2 here $>$

One participant discussed the importance of using partnerships to advance social intrapreneurship and to solidify agency services and programs:

"In the last five years we have launched a program where we have wellness and support advocates who are peer support - these are people with mental illness, in recovery, who are helping other people with mental illness. But rather than basing them here, we place them in other social service organizations to outreach their clients, [for instance] at the 
domestic violence shelter, [women who come] in with domestic violence issues, but have mental health [challenges] that have not been addressed and need help to where they can address it, and knowing how to link..."

Another participant solicited in-kind donations and exchanged some for cash as a way of

advancing agency goals, managing within challenging financial environment and utilizing social intrapreneurship:

"It's amazing what we have been able to do on very little... We do that because we partner with people. We get food drives, food donations, we go to the Harvesters then we go to country fairs, the American Royals and we get food donated. When they are buying hogs and...then they donate it to us. So then we are able to take that to the food processing plant and then they give us gift cards... because of course we don't have enough storage space for [all this food]."

Still another illustration illuminates how, through a social intrapreneurship approach, a social worker leveraged a partnership in creative ways to meet multiple goals and clients' needs in a more comprehensive fashion, while advancing the agency:

"So like we would be working and negotiating with the hospital. And say OK, if you want a family room it will cost $\$ 100,000$ and here are the elements: you need three bedrooms and a kitchen area and a living room area, a place for private family consultation. When the families are inside the hospital, there is medical staff coming in there talking to the family. We...have all a set up of what has to happen and what the price tag is. Then we would work with the hospital and set that up. We would provide staffing. They just provide the space."

Finally, a participant, operating as a social entrepreneur, demonstrated the benefits of partnerships and collaborations:

"So it was really a) moving towards specialization and b) moving towards eliminating competition for those [limited dollars] with one another [within the newly formed organization]. Also developing within our system a continuum of care which allowed us to be more attractive to referral sources, especially third party insurance companies. [This] enabled us to generate new referral sources and broaden our referral base." 
Clearly, with the range of initiatives, ventures and strategies deployed by participants to create sustainable system-level changes for the clients, participants were also able to ensure financial sustainability of these initiatives by either generating revenue or cutting costs.

\section{Preparedness}

Participants shared dimensions of their MSW training that has been useful to them in designing innovative interventions, and components of their academic training that could be enhanced. Some participants were of the opinion that the graduate level training enhanced their critical thinking skills, ability to analyze issues, conduct clinical intervention, and build relationship with diverse constituents. One participant stated:

"Where that [MSW] helped was the ability to critically think through all levels of scenarios...look at the climate of our politics, look at the thing that were happening [at] regional, state, [and] federal levels. Being able to be accountable for what to do with our clients, to our staff, our funding sources and to potential grant funding sources. [I would like to either pursue a JD or a doctoral degree] and think that educational process could help so much further my want or need to reach the community and reach the state level [official], and will afford me the time to research and do the specifics that I see needed to revamp the state system."

Another participant thought that with additional qualifications (JD or Ph.D), she would be able to examine state level service delivery systems and initiate system change to make it more efficient. Another participant stated:

"I am a social worker by profession [however], I probably identify myself more as a nonprofit executive more than anything else."

Some participants realized the need for more training related to data management, comfort with the organization's IT system, and quantitative data analysis for decision making. For example, one participant stated:

"I think it is one of those things you get out there and learn it by doing it. I think there are not that many of us out there that are data geeks, and also care about staff [and] ...clients...I took the outcomes and development class at... and it was a good 
class...I found myself wanting more of a deeper approach on how to collect data not just for sake of data, but how the data can be utilized... [using] Access and Excel [spreadsheets]."

Other participants discussed the importance of being comfortable with budgeting and finance to be successful as a social work entrepreneur. They discussed the need for all social work students to be exposed to this content area to support their future trajectory. One participant stated:

"If you are going to be a social worker in this field and work in the nonprofit arena, you end up having to know a little more about budgeting and financing than social workers sometimes think that they didn't need to know.... Sometimes social workers end up in roles of leadership or supervision and they are not quite prepared for that."

"HR management, HR law. Let me tell you how quickly you can get yourself into trouble with Wage and Labor. Retirement law. Basic HR law. I had a finance class and book tiled "financial management for non profit agencies." How do you do zero based budget, indirect cost allocations... [I didn't know and if I knew] that would have been great. I learned that [on the job] and am still learning that."

Respondents recommended importance of both macro and micro practice courses in their

graduate social work program. These courses helped respondents with understanding the breadth and depth of issues, particularly client dynamics and direct practice staff experiences. They also helped with identifying larger organizational and systemic strategies to address societal issues.

"My clinical experience, they don't have my kind of social work specialty anymore in most universities, but what I was able to get, they called advanced practice social work degree, where I am 50\% administratively trained and 50\% clinically trained... But that don't offer that anymore....I had a good combination.... [Unfortunately, these days in $M S W$ programs, students are in a dilemma] do I go the clinical [route] or do I go the administrative route?"

Another participant identified the importance of taking a course on grant writing and fund development:

"My best administrative class where the project [required us to] write a grant proposal. How many hears have I been doing this already [hence it was very easy, and no new information was learned]. 6 months ago, I had started a nonprofit corporation [with a new program idea]. My group [in class], being the over achievers, conceptually started a non-profit, we drafted our board of directors. " 
An additional participant commented about the importance of focusing on critical thinking within social work programs:

My training taught me, indirectly, to be an innovative creator, a social entrepreneur or intrapreneur]. When I moved here, I was hired at ... Hospital-which doesn't exist anymore - to start a social work department. And they didn't have a social worker and I felt comfortable doing that. I didn't know about social work in hospitals, but I was comfortable with starting something from scratch because I had done that before. [My groups training in social work prepared me to launch a program/department in any field of practice]. It was working with a group, and I saw the hospital as a group and where did social work fit, and having to create a place, and work with all the different modalities and all the different systems. It was a big challenge and it was fun...I saw that social work was the key [in a hospital setting because] it put all the pieces together [for the clients/ patients]. So that was [entrepreneurship or] entrepreneurial, yes.

One participant stated that though the MSW training did not prepare them to transition smoothly from a clinician into an administrator, social intrapreneur or social entrepreneur, it assisted and facilitated their introspection and pursuit of a passion to serve a particular disenfranchised group in society.

Finally, the participants identified that there was a drive and desire to create lasting change at a larger scale in the community. Some participants had mentors who were creative and innovative, others learned on the job by enrolling in specific training, yet others pulled themselves by their bootstraps. Several participants recommended promoting dual degree graduate programs-MSW/MPA or MSW/MBA.

\section{Patterns: Relationships Between Themes}

Apparently, all participants demonstrated predispositions to take on challenging roles at early stage in their career. They demonstrated their propensity to handle challenges in different jobs even before their current roles as social intrapreneurs and social entrepreneurs. They were lifelong learners. One participant noted: 
Even my early career was with.... Being a large bureaucratic organization they hand stuff on how to supervise, and about goals, objectives [and how to conceive and write them annually]. You go to a grant writing class and you learn about [writing grants]. Yes, [I acquired the necessary skills and knowledge] in a whole variety of different places. There was no one place that gave it all [at one time on how to run organizations. I picked up things along the way in my life and learned and stored them and then used them when necessary in my role as a CEO. I have my own mosaic of knowledge collected through out my career that I bring to this position], Yes. At the... I learned how to do performance evaluation, in a bureaucratic there are some advantages to [working in such a setting because you learn about so many useful structures and process that you can later utilize in different forms of organizations]. The other thing I learned was to be a continual learner and self-evaluation."

Another participant noted that, growing up, he witnessed his father as an entrepreneur, and later

used social intrapreneurial techniques to sustain social service programs:

"My personal... [level of readiness] was that my father was an entrepreneur and [at that time] I didn't use the word, I didn't know [at that time]. He owned several small businesses and I saw him do his stuff. He was dad who worked, that's all I knew. And as I got older, I figured out that what he was doing was this stuff and he was kind of creating something from nothing. He was taking advantage of lots of other smart people in what he did. So I guess I learned by watching without understanding what I was watching as a young kind. Then when I was in undergraduate and graduate school, I worked for a startup not-for-profit. There was no money, it was a 4 state [program] there was Title XX money, very little state or federal money for starting a home for delinquent kids. And we went out on weekends and gave speeches at churches and Rotary Clubs and what we came back in cash is what we lived on."

Another important relationship existed between partnerships, collaborations, and participants' ability to take risks and be innovative. Almost all respondents mentioned that without relationship development, nurturing, and trusting partnerships, their roles as social intrapreneurs and social entrepreneurs would have been impossible. Being trained in working with groups, social work practice, community organizing, and planning and development reinforced the importance of building relationships. That was tacit knowledge that they used during the social intrapreneurship and social entrepreneurship journey. As one participant noted:

"I have learned so much as I have gone [and developed so many partnerships over the years in different roles]. [One cannot assume the role of an ED, fresh, on shoe string 
budget. One needs to have a very thick network of partnerships to survive on this budget and make an impact.] ... The management...the ones who are probably looking at [those opportunities and partnerships constantly] because there is no time [for others to travel the path of exploration]. So I am not so sure it is education that is needed, but it is time."

Finally, several participants engaged clients to design programs, ventures and strategies for creating sustainable impact in the community. This engagement greatly assisted them with generating ideas as well as with financial viability of the programs.

\section{Discussion \& Implications}

The participants were sensitive to the changing social, political and economic context of nonprofits in the U.S. Several of them understood the importance of creating systemic changes to truly create the desired impact. They recognized opportunities in the environment and the level of risk they wished to take impacted the scale of change they created (Zahra et al.,2008). They were not afraid of the daunting tasks at hand and took the initiative to acquire knowledge (e.g., legal) and practice skills (e.g., IT, budget) for successfully launching social intrapreneurship initiatives or social entrepreneurship ventures. Their graduate degrees primarily assisted them with identifying and understanding critical social issue(s) and with building and nurturing relationships and partnerships with different constituencies.

Innovation in the social sphere means accomplishing more with less, working together, leveraging resources for creating sustainable change. The illustrations of social intrapreneurship and social entrepreneurship in this article speak to these characteristics. Particularly, community based collaborations can facilitate social innovations (Mulroy \& Shay, 1997). Almost all participants identified the thick networks they had with other nonprofits, public and for-profit organizations. At least five participants provided illustrations of how they involved members of the marginalized groups to generate new ideas and build capacity (Sakarya et al., 2012). Before designing any socially innovative programs, initiators should be aware of already existing 
programs, organizations, resources, attitudes in the community, and preconceived notions about change (Mulroy \& Shay, 1997; Tedmanson \& Guerin, 2011). Participants took these elements into account and designed programs that were less reliant on traditional government funds. Even though adequate funding is often cited as a major impediment to implementing innovative ideas (Salamon et al., 2010), time commitments and finding the balance to juggle different roles and responsibilities was more of a challenge for participants in this study. Even though involving employees in designing and implementing innovative ideas is recommended (Cohen, 1999), once again, time constraints made this difficult for many participants.

Individual characteristics of needing to achieve, work autonomously, exercise internal locus of control, take responsibility for large-scale impact, and take calculated risks (Schmitz \& Scheuerle, 2012) were noted among many participants. In the way they approached contextual changes and challenges demonstrated these characteristics throughout their careers. When they saw that prevailing wisdom for addressing endemic social issue was not working (Light, 2009), they decided to carve out innovative strategies to address them. The participants were able to connect the dots in nonconventional fashion, based on their life and professional experiences and academic training (Barons, 2006). Participants successfully galvanized organizational actors and individuals when they designed social entrepreneurship ventures (Ratten \& Welpe, 2011). They used macro practice skills and business knowhow in their social entrepreneurship and social intrapreneurship initiatives (Germak \& Singh, 2010).

Michael Porter recommends that business education should not focus on creating narrow specializations on social entrepreneurship, corporate social responsibility etc., but should move these concepts into mainstream business education to prepare graduates for the capitalism in a global context (Driver, 2012). He thinks that students today are more socially conscious and 
need to be taught courses in grassroots movements and social activism within business programs. Unless entrepreneurial competencies are taught and practiced within academic programs, graduates from these programs will not demonstrate the behaviors in the real work context (Mojab, Zaefarian, \& Azizi, 2011). Initiative, ambition, and critical and analytical thinking were key characteristics for entrepreneurship in the study completed by Mojab et al. However, motivations among individuals who demonstrate entrepreneurial traits are hard to teach because this is more intrinsic and often engrained in individuals (Mojab et al., 2011).

Faculty educators can identify innovative and entrepreneurial thinkers early in their careers and give them the skill set and coaching to engage in successful social intrapreneurship and social entrepreneurial activities (Light, 2008). Clearly, the Masters in Social Work curriculum provided a perspective and a skills-set to participants which assisted them with some elements of social intrapreneurship and social entrepreneurship, e.g., critical analysis of issues, building relationships with diverse constituencies, passion to work with specific population groups, program development to an extent, and clinical intervention. However, participants shared academic deficits in areas such as, technology and data management, management, writing grants, accounting and human resource administration. No formal training, within the MSW program curriculum, on social intrapreneurship, social entrepreneurship and social innovation was provided to the participants.

While social work has largely ignored social intrapreneurship and social entrepreneurship, there are some notable exceptions. Today, a few schools of social work now offer courses in social entrepreneurship (e.g., George Warren Brown, n.d.; University of Central Florida, n.d.; Boston College Graduate School of Social Work, n.d.; University of Illinois, Champaign-Urbana, n.d.). Despite these few exceptions, most social entrepreneurship courses, 
majors, and concentrations remain in schools of business or public administration and the curricula reflects the knowledge, values, and skills associated with their respective disciplines. Such curricula offer students little or no content on important subjects such as culture, community engagement, social justice and working with oppressed populations. In this respect, social work can play a critical role in social intrapreneurship and social entrepreneurship education and practice. Social work educators are well positioned and prepared to offer social entrepreneurship and social intrapreneurship courses and programs (Nandan \& Scott, 2013). The Educational and Policy Accreditation Standards (EPAS) recommend innovative program development. However, the social work curriculum should emphasize and reflect this behavior development. By directing greater attention and focus in this area, the profession can broaden its influence and encourage social workers to practice as innovative change agents. Dual degree programs and continuing education courses on these topics can become increasingly available to social work students and practitioners, in order to prepare them for social innovation, social intrapreneurship and social entrepreneurship (Nandan \& Scott, 2013). 


\section{References}

Aspen Institute (2009). The emerging fourth sector: Executive Summary. Washington DC: The Aspen Institute.

Bacq, S., \& Janssen, F. (2011). The multiple faces of social entrepreneurship: A review of definitional issues based on geographical and thematic criteria. Entrepreneurship \& Regional Development, 23(5-6), 373-403. doi:10.1080/08985626.2011.577242

Barendsen, L., \& Gardner, H. (2004). Is social entrepreneur a new type of leader? Leader to Leader, 34, 43-50. doi:10.1002/1tl.100

Barons, R. A. (2006). Opportunity recognition as pattern recognition: How entrepreneurs 'connect dots' to identify new business opportunities. Academy of management perspective, 20(1), 104-119. doi:10.5465/AMP.2006.19873412

Bent-Goodley, T. B. (2002). Defining and conceptualizing social work entrepreneurship. Journal of Social Work Education, 38(2), 291-302. doi: 10.1080/10437797.2002.10779098

Boston College Graduate School of Social Work, (n.d.). Retrieved July 14, 2014, from http://www.bc.edu/content/bc/schools/csom/graduate/courses/gsomspring/springad/mb84 001.html

Bouchard, V., \& Basso, O. (2011). Exploring the links between entrepreneurial orientation and intrapreneurship in SMEs. Journal of Small Business and Enterprise Development, 18(2), 219-231. doi:10.1108/14626001111127043

Brinckerhoff, P. C. (2000, November 30). Social Entrepreneurship. Chronicle of Philanthropy, 13(4).

Brown, L. (2010). Balancing risk and innovation to improve social work practice. British Journal of Social Work, 40(4), 1211-1228. doi: 10.1093/bjsw/bcq013 
Brunaker, S., \& Kurvinen, J. (2006). Intrapreneurship, local initiatives in organizational change processes. Leadership and Organization Development Journal, 27(2), 118-132. doi:10.1108/01437730610646624

Burgelman, R. A. (1983). A process model of internal corporate venturing in the diversified major firm. Administrative Science Quarterly, 28(2), 223-244. Retrieved from http://www.jstor.org/stable/2392619

Carland, J. C., \& Carland, J. W. (2007). Intrapreneurship: A requisite for success. The Entrepreneurial Executive, 12, 83-94. Retrieved from http://www.alliedacademies.org/public/journals/JournalDetails.aspx?jid=9

Cohen, B. J. (1999). Fostering innovation in a large human services bureaucracy. Administration in Social Work, 23(2), 47-59. doi:10.1300/J147v23n02_04

Companys, Y. E., \& McMullen, J. S. (2007) Strategic entrepreneurs at work: The nature, discovery, and exploitation of entrepreneurial opportunities. Small Business Economics, 28, 301-322. doi:10.1007/s11187-006-9034-x

Dacin, P. A., Dacin, M. T., \& Matear, M. (2010). Social entrepreneurship: Why we don't need a new theory and how we move forward from here. Academy of Management Perspectives, 24(3), 37-57. Retrieved from http://amp.aom.org/content/24/3/37.abstract

Dees, J. G. (1998) "The Meaning of SE", Retrieved from http://www.caseatduke.org/documents/dees_sedef.pdf

Driver, M. (2012). An interview with Michael Porter: Social entrepreneurship and the transformation of capitalism. Academy of Management Learning \& Education, 11(3), 421-431. doi: 10.5465/amle.2011.0002A 
George Warren Brown School of Social Work, (n.d.). Retrieved July 14, 2014, from http://brownschool.wustl.edu/Admissions/MSWProgram/Documents/MSW\%20Social\%2 0Entrepreneurship\%20Specialization.pdf

Gray, M., Healy, K., \& Crofts, P. (2003). Social enterprise: Is it the business of social work? Australian Social Work, 56(2), 141-164. doi:10.1046/j.0312-407X.2003.00060.x

Germak, A.J., \& Singh, K.K. (2010). SE: Changing the way social workers do business. Administration in Social Work, 34(1), 79-95. doi:10.1080/03643100903432974

Hayton, J. C., George, G., \& Zahra, S. A. (2002). National Culture and Entrepreneurship: A review of behavioral research. Entrepreneurship Theory and Practice, 26(4), 33-52. Retieved from http://www.taranomco.com/wp-content/uploads/2013/11/71.pdf

Helm, S. T., \& Andersson, F. O. (2010). Beyond Taxonomy: An empirical validation of social entrepreneurship in the nonprofit sector. Nonprofit Management and Leadership, 20(3), 259-276. doi:10.1002/nml.253

Jarman-Rohde, L., McFall, J., Kolar, P., \& Strom, G. (1997). The changing context of social work practice: Implications and recommendations for social work educators. Journal of Social Work Education, 33(1), 29-46. doi:10.1080/10437797.1997.10778851

Jansson, B. (2011). Becoming an effective policy advocate ( $6^{\text {th }}$ ed.). Belmont, CA: Brooks/Cole. Lawler, J., \& Bilson, A. (2010). Social Work Management and Leadership: Managing Complexity with Creativity. London: Routledge.

Light, P. C. (2008). The search for SE. Washington DC: Brookings Institute Press.

Light, P. C. (2009). Social entrepreneurship revisited. Stanford Social Innovation Review, 7(3), 21-22. Retrieved from http://www.ssireview.org/articles/entry/social_entrepreneurship_revisited 
Linton, K. F. (2013). Developing a social enterprise as a social worker. Administration in Social Work, 37(5), 458-470. doi:10.1080/03643107.2013.828000

Mair, J., \& Marti, I. (2006). Social Entrepreneurship Research: A Source of Explanation, Prediction, and Delight. Journal of World Business, 41, 36-44. doi:10.1016/j.jwb.2005.09.002

Mojab, F., Zaefarian, R., Azizi, A. H. D. (2011). Applying competency based approach for entrepreneurship education. Procedia Social and Behavioral Sciences, 12, 436-447. doi:10.1016/j.sbspro.2011.02.054

Moore, M., \& Westley, F. (2011). Surmountable chasms: Networks and social innovation for resilient systems. Ecology and Society, 16(1), 5. Retrieved from http://www.ecologyandsociety.org/vol16/iss1/art5/

Mort, G., Weerawardena, J. \& Carnegie, K. (2003). SE: Towards conceptualization. International Journal of Nonprofit and Voluntary Sector Marketing, 8(1), 76-88. doi:10.1002/nvsm.20.

Mulroy, E. A., \& Shay, S. (1997). Nonprofit organizations and innovation: A model of neighborhood-based collaboration to prevent child maltreatment. Social Work, 42(5), 515-524. doi: 10.1093/sw/42.5.515.

Munshi, N. V. (2010). Value creation, social innovation, and entrepreneurship in global economies. Journal of Asia-Pacific Business, 11, 160-165.

Nandan, M. \& Scott, P. (2013). Social entrepreneurship and social work: The need for a transdisciplinary education model. Administration in Social Work. 37(3), 257-271. Retrieved from http://www.tandfonline.com/eprint/YD8HfBV5ekEfM6mFT2Dd/full 
Nandan, M. London, M., \& Blum, T. (2013). Community practice social entrepreneurship: An interdisciplinary approach to graduate education. International Journal of Social Entrepreneurship and Innovation, 3(1), 51-70.

Nee, E. (2009) Idea, Q \& A, Stanford Social Innovation Review, 7(3), 13-15.

Pantry, S., \& Griffiths, P. (2000). Being an intrapreneur and creating a successful information service within your organization. Business Information Review, 17(4), 205-214. doi:10.1177/0266382004237773

Patton, M. Q. (2001). Qualitative Research and Evaluation Methods, $3^{\text {rd }}$ ed. Thousand Oaks, CA: Sage Publications.

Peredo, A. M., \& McLean, M. (2006). SE: A critical review of the concept. Journal of world business, 41, 56-65. doi:10.1016/j.jwb.2005.10.007

Perrini, F. (2006). Social entrepreneurship domain: Setting boundaries. In Perrini, F. (Ed.) The new SE: What awaits social entrepreneurial ventures? (pp.1-25). Northampton, MA: Edward Elgar.

Phills, J. A., Deiglmeier, K., \& Miller, D. T. (2008). Rediscovering social innovation. Stanford Social Innovation Review, 6(4), 34-43. Retrieved from http://www.ssireview.org/articles/entry/rediscovering_social_innovation/

Phills, J. A., \& Nee, E. (2009). From crisis comes opportunity. Stanford Social Innovation Review, 7(1), p. 4.

Pol, E., \& Ville, S. (2009). Social innovation: Buzz word or enduring term? The Journal of Socio-Economics, 38, 878-885. doi:10.1016/j.socec.2009.02.011

Praszkier, R., \& Nowak, A. (2012). Social entrepreneurship: Theory and practice. New York, NY: Cambridge University Press. 
Ratten, V., \& Welpe, I. M. (2011). Special issue: Community-based, social and societal entrepreneurship: Guest editorial. Entrepreneurship and Regional Development, 23(5-6), 283-286. doi: 10.1080/08985626.2011.580159

Sakarya, S., Bodur, M., Yildirim-Öktem, Ö., \& Selekler-Göksen, N. (2012). Social alliances: Business and social enterprise collaboration for social transformation. Journal of Business Research, 65(12), 1710-1720. doi:10.1016/j.jbusres.2012.02.012

Salamon, L. M., Geller, S. L., \& Mengel, K. L. (2010). Nonprofits, innovation, and performance measurement: Separating fact from fiction. Listening Post Project, 17, 1-25. Retrieved from http://ccss.jhu.edu/wpcontent/uploads/downloads/2011/09/LP_Communique17_2010.pdf

Schmitz, B., \& Scheuerle, T. (2012). Founding or transforming? Social intrapreneurship in three German Christian-based NPOs. ACRN Journal of Entrepreneurship Perspectives, 1(1), 13-36. Retrieved from http://www.acrn.eu/resources/Journals/JoE012012/Schmitz_Intrapreneurship.pdf Short, J.C., Moss, T.W., \& Lumpkin, G.T. (2009). Research in social entrepreneurship: Past contributions and future opportunities. Strategic Entrepreneurship Journal, 3(2), 161194. doi: $10.1002 /$ sej.69

Tapsell, P., \& Woods, C. (2010). Social entrepreneurship and innovation: Self-organization in an indigenous context. Entrepreneurship \& Regional Development, 22(6), 535-556. doi:10.1080/08985626.2010.488403

Tedmanson, D., \& Guerin, P. (2011). Enterprising social wellbeing: Social entrepreneurial and strengths based approaches to mental health and wellbeing in "remote" indigenous 
community contexts. Australasian Psychiatry, 19(1), 30-33.

doi:10.3109/10398562.2011.583078

University of Central Florida. (n.d.). Retrieved July 14, 2014, from http://www.graduatecatalog.ucf.edu/programs/program.aspx $? \mathrm{id}=1374 \& \mathrm{tid}=3588 \&$ track= Social\%20Work

University of Illinois, Champaign-Urbana. (n.d.). Retrieved July 14, 2014, from http://socialwork.illinois.edu/academics/master-of-social-work/msw-course-descriptions/

Woocher, J. (2011). Innovation and Beyond. Journal of Jewish Communal Service, 86(1/2), Winter/Spring, 77-82. Retrieved from http://www.bjpa.org/Publications/downloadPublication.cfm?PublicationID=13796

Young, H. P. (2011). The dynamics of social innovation. PNAS, 108(4), 2185-2291.

Zahra, S. A., Rawhouser, H. N., Bhawe, N., Neubaum, D. O., \& Hayton, J. C. (2008). Globalization of social entrepreneurship opportunities. Strategic Entrepreneurship Journal, 2, 1-15. doi: 10.1002/sej.43

Zadek, S. \& Thake, S. (1997, June 20). Send in the social entrepreneurs. New Statesman, 126(4339), 31.

Zongker, B. (2010, October 18). Charity groups see big decline. The Kansas City Star, pp. A1, A12. 
Running head: SOCIAL WORKERS AS SOCIAL CHANGE AGENTS 